\title{
Palaeogene deposits in North-East Greenland
}

\author{
Henrik Nøhr-Hansen, Lars Henrik Nielsen, Emma Sheldon, Jussi Hovikoski and Peter Alsen
}

Scattered occurrences of Palaeogene sediments are found in North-East Greenland, where they overlie unconformably Cretaceous sediments and are capped by Palaeogene basalts. These sediments have received little attention (Watt 1994), except for relatively recent studies (Nøhr-Hansen \& Piasecki 2002; Jolley \& Whitham 2004; Larsen et al. 2005; Heilmann-Clausen et al. 2008). As part of an ongoing petroleum geological study that focuses on the Jurassic-Cretaceous succession, the Palaeogene sediments were included to better constrain their age, depositional environment and relation to the basalts. Several localities were investigated on Wollaston Forland, Sabine $\varnothing$ and Hold with Hope, a few of which are described here (Fig. 1).

\section{Eastern Wollaston Forland and Sabine $\boldsymbol{\varnothing}$}

Discontinuous outcrops of mostly loose and un-cemented Palaeogene sediments occur in Haredal, eastern Wollaston Forland. A N-S-striking normal fault with 100-125 m of downthrow to the east separates the main outcrop in the southern slope into two blocks. The best exposed succession is situated in the western footwall block, where the succession dips $20^{\circ}$ to the SW (Fig. 2). It overlies marine mudstones of Late Albian age (Wigginsiella grandstandica Subzone (V1) of Nøhr-Hansen 1993) in the footwall block and of Early to Middle Campanian age (indicated by the dinocysts Alterbidinium ioannidesii and Cerodinium diebelii) in the hanging wall block; however, the contact to the Cretaceous is not exposed. A poorly exposed Palaeogene succession in the northern slope is probably from the hanging wall block; the base of the succession and underlying strata are not exposed.

Haredal, southern slope. Approximately $200 \mathrm{~m}$ of Palaeogene sediments are partly exposed in the footwall block, forming two upward-coarsening units overlain by basalts (Fig. 2). The lower unit consists of more than $70 \mathrm{~m}$ of dark grey mud overlain by $54 \mathrm{~m}$ of fine- to medium-grained sand beds alternating with thinner heteroliths topped by more than $2 \mathrm{~m}$ of coarse-grained sand. The succession is of earliest Ypresian age based on the presence of the dinocyst Apectodinium augustum (Fig. 3) and the nannofossil Discoaster lenticularis. The palynological assemblage is dominated by reworked ma- terial from Upper Jurassic (e.g. Gonyaulacysta jurassica), mid to Upper Cretaceous (e.g. Hapsocysta benteae, Chatangiella spp. and Wodehouseia spinata) and lower Paleocene (e.g. Alisocysta margarita). The presence of $A$. augustum may correlate with the $A$. augustum (P6b) Subzone described from the central North Sea (Mudge \& Bujak 1996) and correlated

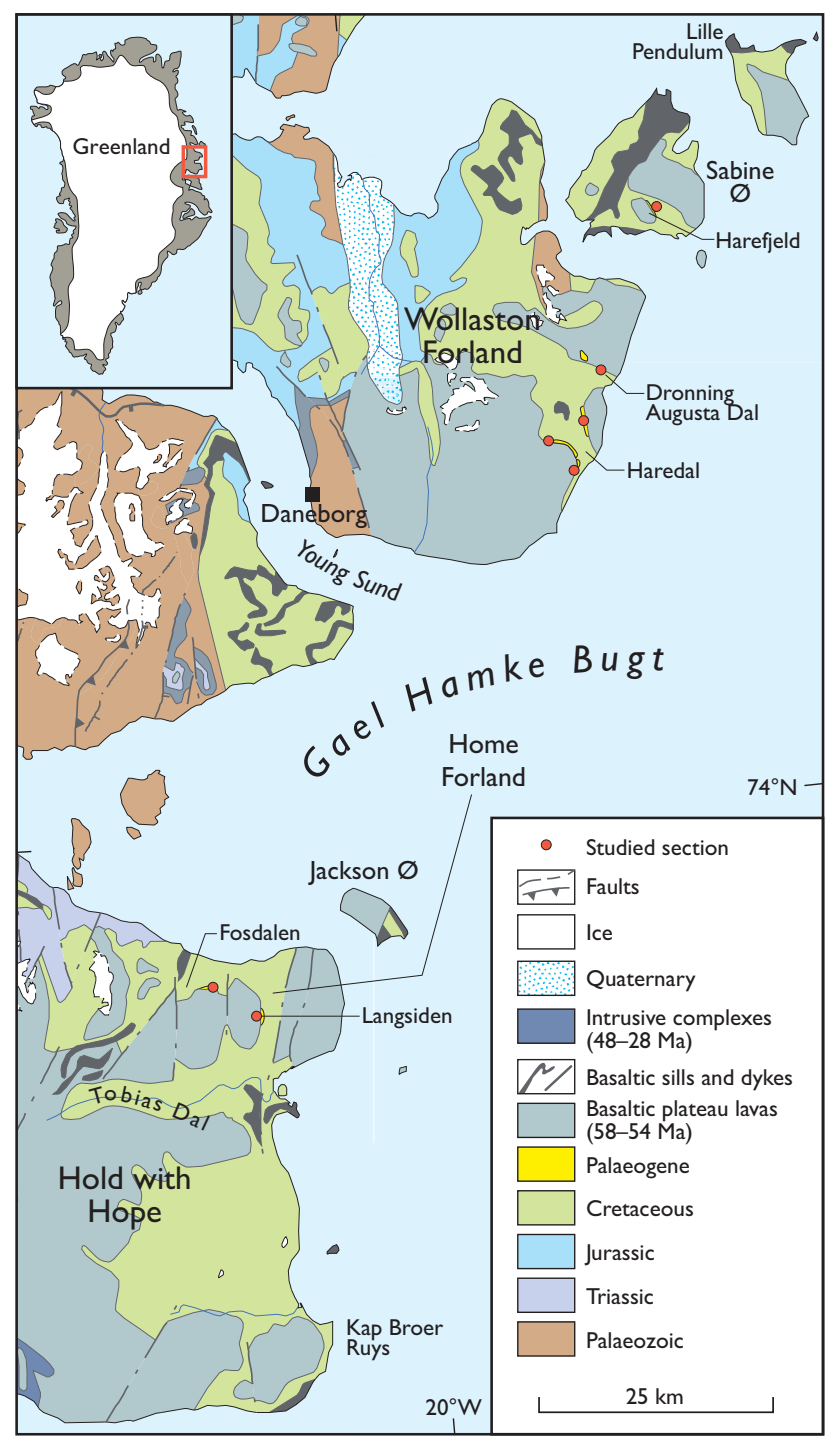

Fig. 1. Geological map of the Wollaston Forland - Hold with Hope study area in North-East Greenland. The location of the studied sections corresponds to the distribution of Palaeogene sediments. 

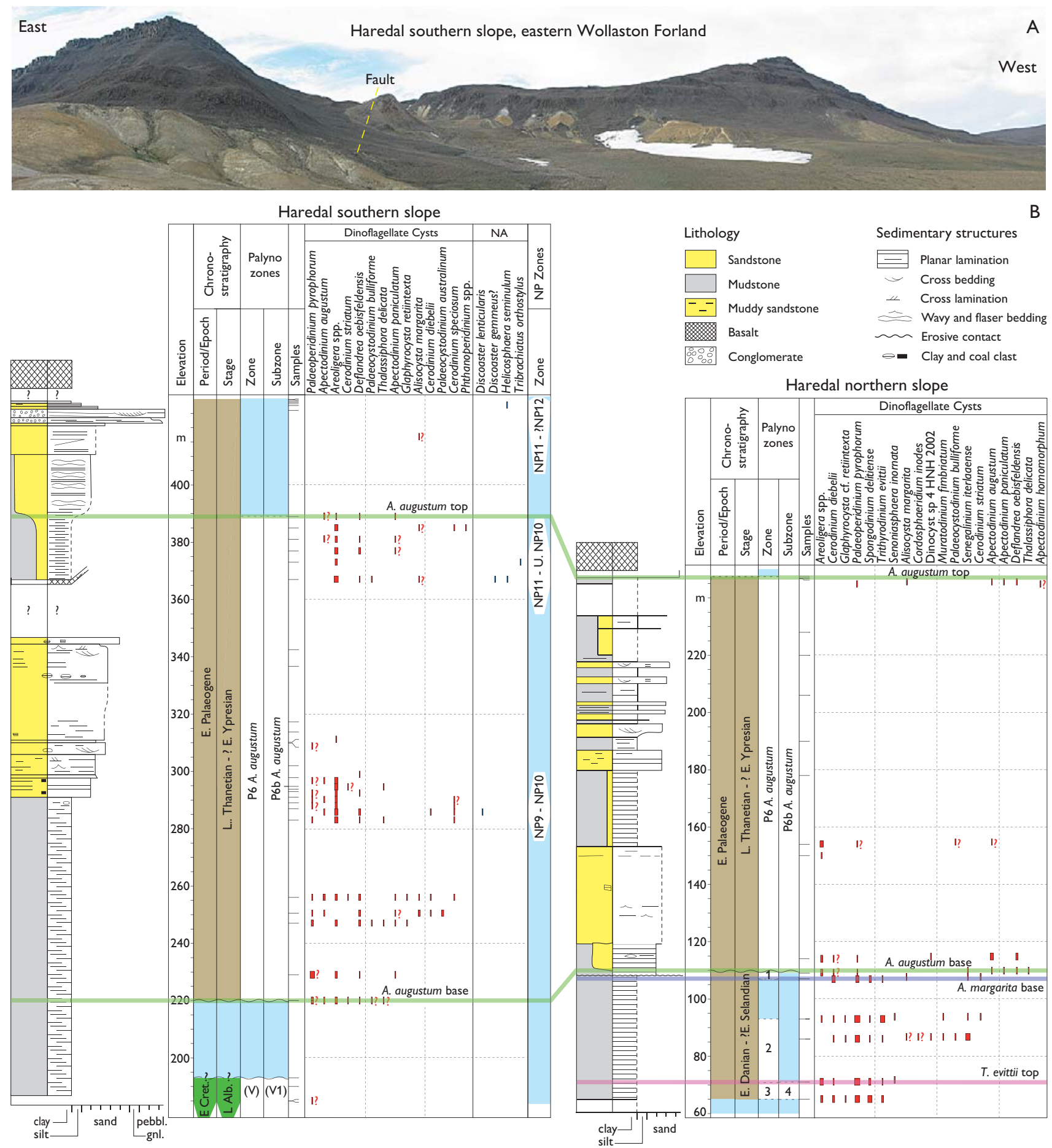

Fig. 2. A: Southern slope and fault at Haredal. The highest mountain is $c .700 \mathrm{~m}$ high. B: Sedimentological logs and range charts of selected in situ dinocysts and calcareous nannofossils. Numerals in the zones of the northern slope are: 1: Alisocysta margarita Zone, 2: Senegalinium iterlaaense Zone or Palaeocystodinium bulliforme Zone, 3: Trithyrodinium evittii Zone and 4: Spongodinium delitiense Subzone (Nøhr-Hansen et al. 2002). NA: Nannofossils, NP: Palaeogene nannoplankton zone. V, V1: Subtilisphaera kalaalliti Zone and Wigginsiella grandstandica Subzone (Nøhr-Hansen 1993).

with the Paleocene-Eocene thermal maximum (PETM) which occurred at about $56 \mathrm{Ma}$ and lasted for $c .170 \mathrm{kyr}$ (Harding et al. 2011). The upper, coarser-grained part only yielded two dinocyst species Cerodinium sp. and Areoligera sp. and no nannofossils.
The upper unit consists of more than $20 \mathrm{~m}$ of dark grey silty and sandy mud overlain by slightly heterolithic, finegrained sand $(22 \mathrm{~m})$, fine-grained sand $(10 \mathrm{~m})$, conglomerate and pebbly sandstone $(8 \mathrm{~m})$ topped by a few metres of sand, mud and carbonaceous mud or coal. The palynologi- 


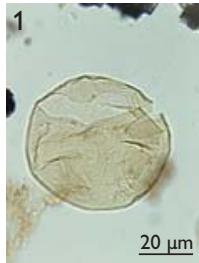

$2 \mathrm{~A}$

$20 \mu \mathrm{m}$

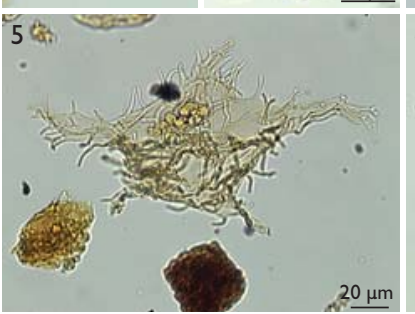

7

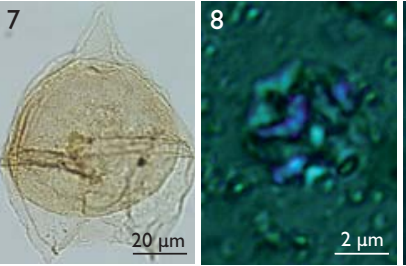

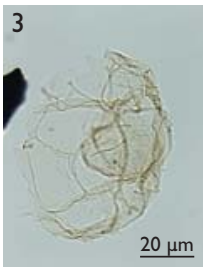

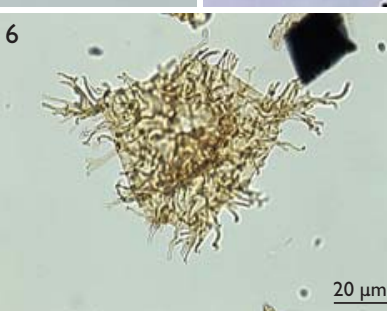

$\underline{20 \mu \mathrm{m}}$

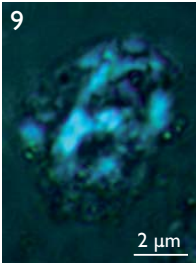

10

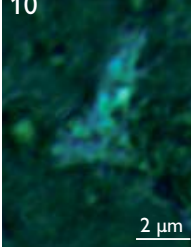

Fig. 3. Images of selected dinocysts (1-7) and nannofossils (8-10). 1: Trithyrodinium evittii. 2A, B: Alisocysta margarita. 3: Thalassiphora delicata. 4: Gen et sp. indet. of Piasecki et al. (1992). 5: Apectodinium augustum. 6: Apectodinium paniculatum. 7: Deflandrea oebisfeldensis. 8: Discoaster gemmeus? 9: Helicosphaera seminulum. 10: Tribrachiatus orthostylus.

cal assemblages below the conglomerate are dominated by reworked material of mid - Late Cretaceous age and a few specimens of Paleocene age. The succession is of early Ypresian (Early Eocene) age based on poorly preserved specimens of the dinocysts Apectodinum augustum, Apectodinium paniculatum, Deflandrea oebisfeldensis and the nannofossil Tribrachiatus orthostylus (Fig. 3). Samples above the conglomerate yielded a few reworked Upper Cretaceous and Paleocene dinocysts together with a few indeterminate algae and the nannofossil Helicosphaera seminulum (Fig. 3). The latter indicates an age not younger than mid Ypresian for the youngest dated sediments in Haredal; this is compatable with a mid Ypresian radiometric ${ }^{39} \mathrm{Ar} /{ }^{40} \mathrm{Ar}$ age of $55.02 \pm 0.49 \mathrm{Ma}$ for the oldest lava analysed from Wollaston Forland (L.M. Larsen personal communication 2008).

Haredal northern slope. Approximately $180 \mathrm{~m}$ of sediments were studied on the northern slope of Haredal (Fig 1). The lower $40 \mathrm{~m}$ consist of dark grey mud with a palynological assemblage dominated by reworked material from mid - Upper Cretaceous strata (e.g. Hapsocysta benteae, Chatangiella spp. and Aquilapollenites spp.). The presence of Trithyrodinium evittii, Spongodinium delitiense and a few specimens of Senoniasphaera inornata in the two lowermost samples indi- cates an Early Paleocene age and may correlate with the lower Danian Trithyrodinium evittii Zone (Fig. 2) established from West Greenland (Nøhr-Hansen et al. 2002). The presence of common Senegalinium iterlaaense and Palaeocystodinium bulliforme in the two overlying samples indicates a mid to late Danian age correlating with the Senegalinium iterlaaense and Palaeocystodinium bulliforme zones (2 and 3 in Fig. 2), whereas the next sample contains a few specimens of the dinocysts Alisocysta margarita and Cerodinium striatum indicating a late Danian/?early Selandian age correlating with the Alisocysta margarita Zone (Nøhr-Hansen et al. 2002; 1 in Fig. 2). The upper $130 \mathrm{~m}$ of sand and mud contain very few in situ palynomorphs, however the presence of Apectodinium augustum indicates correlation with the Apectodinium augustum (P6b) Subzone, indicating an ?early Selandian - Thanetian hiatus.

Outer Haredal, Dronning Augusta Dal and Sabine Ø. Palaeogene sediments from the southern slope of the easternmost part of Haredal, on the eastern slope of Dronning Augusta $\mathrm{Dal}$, and on the north-eastern slope of Harebjerg, Sabine $\varnothing$ were also studied and sampled (Fig. 1).The successions all contain the PETM dinocyst marker Apectodinium augustum.

\section{North-eastern Hold with Hope}

Langsiden. Interbedded in dark grey mud at Langsiden (Fig. 1) occurs an $8 \mathrm{~m}$ thick unit with sharp-based, upwardfining successions of conglomerate and pebbly sand, up to a few metres thick containing large reworked mudstone clasts. The palynological assemblage from the underlying mud is dominated by a reworked flora of late Maastrichtian age indicated by the presence of Triblastula wilsonii and Wodehouseia octospina. The presence of in situ Trithyrodinium evittii, Spongodinium delitiense and a few specimens of $\mathrm{Se}$ noniasphaera inornata indicates correlation with the lower Danian Trithyrodinium evittii Zone (Nøhr-Hansen et al. 2002). The mudstone clasts yielded a mid Cretaceous flora. The palynomorph assemblage of two samples from the overlying mud is likewise dominated by a reworked Upper Cretaceous flora; however, the lower sample also contains a few specimens of the dinocysts Alisocysta margarita and Cerodinium striatum, indicating correlation with the upper Danian/?lower Selandian Alisocysta margarita Zone (NøhrHansen et al. 2002). The presence of Thalassiphora delicata in the upper sample indicates a latest Danian/early Selandian age (Nøhr-Hansen \& Piasecki 2002).

East of Fosdalen. Approximately $6 \mathrm{~m}$ of loose, white-grey, fine- to medium-grained sand with scattered small clay clasts 
overlain by a less than $2 \mathrm{~m}$ thick bed of dark grey mud covered by volcanic rocks overlies mid Cretaceous sandy mudstone east of Fosdalen (Fig. 1). The palynological assemblage of the mud bed is dominated by spores and pollen and some reworked dinocysts of mid to Late Cretaceous age. In situ specimens of the dinocyst gen. et sp. indet. of Piasecki et al. (1992; Fig. 3) also occur, suggesting fresh to brackish water. The species is common in wells offshore eastern Canada just above the Apectodinium augustum P6b Subzone (H. NøhrHansen, unpublished data). The occurrence of the species immediately below the basalts may indicate an earliest Ypresian age.

\section{Discussion}

The new biostratigraphic dating shows that the Palaeogene sediments on Wollaston Forland, Hold with Hope and Sabine $\varnothing$ comprise Paleocene and earliest Eocene strata with a hiatus that probably spans the major part of the Selandian and Thanetian. The age of the underlying Cretaceous deposits east of the fault in Haredal is Early-Middle Campanian, much younger than the Middle Albian previously described from Wollaston Forland (Nøhr-Hansen 1993). The stratigraphic gap between the Cretaceous and Palaeogene sediments thus decreases towards the basin to the east. The large amount of reworked Cretaceous marine palynomorphs including a Late Maastrichtian flora documents uplift of Cretaceous marine sediments and major erosion during the Early Palaeogene. The ages of the youngest Palaeogene sediments and the oldest flood basalts appear to be almost identical; however, the nature of the contact between the sediments and basalts needs to be further investigated to determine whether the contact is angular, as is suggested in places by a relatively steep dip of the sediments.

Discontinuous conglomerate beds with rounded quartzite pebbles and boulders up to $20 \mathrm{~cm}$, as well as cross-bedded sandstones, terminate the upper unit in Haredal and are interpreted as fluvial channel deposits. The absence of basaltic clasts indicates that deposition occurred prior to the volcanic events. The thin overlying succession with a coaly bed is interpreted as an aggrading coastal plain subject to marine inundations. However, the principal part of the Palaeogene sediments accumulated in a marine environment as indicated by marine dinocysts and the presence of scattered marine trace fossils. Thin, fine-grained sandstone beds with flute casts and a massive lower part overlain by beds with parallel lamination and cross-lamination in outer Haredal indicate deposition from turbidite currents. The sharp-based, finingupward conglomerate beds and pebbly sand from Langsiden embedded in mud are interpreted as channelised gravity flow deposits. The two upward-coarsening units in Haredal suggest that the Palaeogene sediments mainly accumulated during two major depositional phases. Potential by-pass surfaces are identified at the Cretaceous-Palaeogene boundary, at the top of the lower unit, at the base of the fluvial conglomerates and possibly at the sediment-basalt boundary. Coarsegrained sediments may have been transported toward the basin area to the east along these surfaces.

\section{References}

Harding, I.C. et al. 2011: Sea-level and salinity fluctuations during the Paleocene-Eocene thermal maximum in Arctic Spitsbergen. Earth and Planetary Science Letters 303, 97-107.

Heilmann-Clausen, C., Abrahamsen, N., Larsen, M., Piasecki, S. \& Stemmerik, L. 2008: Age of the youngest Paleogene flood basalts in East Greenland. Newsletters on Stratigraphy 43, 55-63.

Jolley, D.W. \& Whitham, A.G. 2004: A stratigraphical and palaeoenvironmental analysis of the sub-basaltic Palaeogene sediments of East Greenland. Petroleum Geoscience 10, 53-60.

Larsen, M., Heilmann-Clausen, C., Piasecki, S. \& Stemmerik, L. 2005: At the edge of a new ocean: post-volcanic evolution of the Palaeogene Kap Dalton Group, East Greenland. In: Doré, A.G. \& Vining, B. (eds): Petroleum geology: North-West Europe and global perspectives. Proceedings of the 6th Petroleum Conference London 2, 923-932. London: Geological Society.

Mudge, D.C. \& Bujak, J.P. 1996: Paleocene biostratigraphy and sequence stratigraphy of the UK central North Sea. Marine and Petroleum Geology 13, 295-312.

Nøhr-Hansen, H. 1993: Dinoflagellate cyst stratigraphy of the Barremian to Albian, Lower Cretaceous, North-East Greenland. Grønlands Geologiske Undersøgelse Bulletin 166, 171 pp.

Nøhr-Hansen, H, \& Piasecki, S. 2002: Palaeocene age of sub-basaltic sediments at Savoia Halvø, East Greenland. Geology of Greenland Survey Bulletin 191, 111-116.

Nøhr-Hansen, H., Sheldon, E. \& Dam, G. 2002: A new biostratigraphic scheme for the Paleocene onshore West Greenland and its implications for the timing of the pre-volcanic evolution. In: Jolley, D.W. \& Bell, B.R. (eds): The North Atlantic Igneous Province: stratigraphy, tectonic, volcanic and magmatic processes. Geological Society, Special Publications (London) 197, 111-156.

Piasecki, S., Larsen, L.M., Pedersen, A.K. \& Pedersen, G.K. 1992: Palynostratigraphy of the Lower Tertiary volcanics and marine clastic sediments in the southern part of the West Greenland Basin: implications for the timing and duration of the volcanism. Rapport Grønlands Geologiske Undersøgelse 154, 13-31.

Watt, W.S. 1994: Stratigraphy and correlation of the Tertiary plateau basalts in North-East Greenland. Rapport Grønlands Geologiske Undersøgelse 162, 185-194. 